UDK 37.091.26

Pregledni rad

Primljeno: 07.12.2020.

Odobreno za štampu: .12.2020.

DOI: https://doi.org/10.46630/gped.2.2020.04

\title{
ОЦЕЊИВАЊЕ УЧЕНИКА У АЛТЕРНАТИВНИМ ШКОЛАМА
}

Тамара Вукић $^{1}$
Унивезитет у Нишу, Филозофски факултет, Департман за педагогију, докторанд

\section{Марија Јовановић}

Унивезитет у Нишу, Филозофски факултет, Департман за педагогију

Ancmpaкm: Кључне претпоставке обезбеђивања квалитета образовања и процеса наставе јесу квалитативне особености процеса оцењивања и његова ефикасност. У намери да прикажемо вредности, улогу и значај карактеристика оцењивања које су у систему савременог редовног образовања значајно занемарене или потпуно одсутне, у раду је дат приказ алтернативних школа у којима се процес евалуације и оцењивања управо заснива на оваквим квалитативним приступима. У раду су представљене опште карактеристике васпитно-образовног рада Валдорфске школе, Монтерсори школе и Френеове школе, са посебним освртом на процес оцењивања и евалуације. На основу одлика оцењивања у приказаним алтернативним школама може се закључити да овај процес карактеришу: холистички приступ; висок ниво индивидуализације; мотивација наспрам категоризације; сарадња и заједничка одговорност наставника, ученика и родитеља; благовремена повратна информација као основа самоевалуације и одсуство репресивног деловања оцене. Утврђене карактеристике пружају могућност за креирање иновативних техника и механизама процене којима се може обезбедити квалитет и ефикасност процеса оцењивања и у систему редовног образовања и послужити као основа на креирање индивидуализованих поступака оцењивања којима наставници практичари могу у значајној мери унапредити своју праксу а оцењивање у већој мери ставити у функцију развоја ученика.

Кључне речи: оцењивање, алтернативне школе, Валдорфска школа, Монтерсори школа и Френеова школа

\section{Увод}

Систематско представљање особености процеса евалуације и оцењивања у алтернативним школама захтева познавање концепта алтернативног образовања и основних постулата алтернативних школа. У најопштијем смислу, под појмом ,алтернативно образовање“ подразумева се образовање изван тради-

\footnotetext{
${ }^{1}$ tamaravukic93@gmail.com
} 
ционалне школе (Siegrist et al., 2010). Иако тумачење термина „алтернативне школе“ и ,алтернативно образовање“ варира у зависности од места и времена на које се односи (Milutinović \& Zuković, 2013; Nagata, 2006), опште карактеристике алтернативних школа су: (1) усмереност на развој блиских интерперсоналних веза међу свим актерима образовног процеса; (2) наставни садржаји често нису подељени на предмете, већ рефлектују интегративне теме у оквиру којих ученици усвајају знања из више различитих научних дисциплина; (3) фокус је на активном учењу, односно учењу путем делања, и искуственом учењу; (4) промоција самоевалуације и самопроцене ученика; (5) креирање што мање школских правила, са већом партиципацијом ученика у доношењу индивидуалних и колективних одлука (Milutinović, 2011).

Без обзира на то што се савремене алтернативне школе могу разликовати од ранијих, све алтернативне школе повезује иста филозофија: једна (иста) величина не одговара свима (Cable et al., 2009). У конвенционалном образовању се обично говори о „индивидуалним потребама“, али оне су подређене стандардима, што значи да се очекује да сва деца постигну мерљиве резултате у предвиђеном року (Martin, 2004), односно да следе унапред припремљен и стандардизован курикулум (Milutinović i Zuković, 2011). Насупрот томе, алтернативне школе се одупиру униформности коју захтевају стандарди, што значи да се у оквиру алтернативног приступа образовању ученик посматра као индивидуа (Martin, 2004). Ове школе заснивају се на претпоставкама хуманистичког, слободног и демократског образовања а самоевалуацију сматарају једином смисленом формом провере успеха и резултата у учењу. Ученик се посматра као самоодговорна, унутрашње мотивисана особа, те похађање наставе није обавезно, а не спроводи се ни оцењивање у виду редовних стандардних облика тестирања и усменог проверавања. Искључивање присиле и омогућавање избора у учењу су темељи за израстање ученика у индивидуе способне да доносе изборе, самостално размишљају, изражавају осећања, решавају конфликте и активно учествују у друштву и заједници (Milutinović i Zuković, 2011).

Сходно основном концепту, као једна од карактеристика програма ефикасних алтернативних школа, издвајају се и алтернативне методе оцењивања, које су прилагођене различитим стиловима учења и којима се ученици подстичу на остваривање академског успеха (Reimer \& Cash, 2003). У циљу представљања особености, улоге и значаја који овакав концепт оцењивања и евалуације има, у наставку је приказана пракса оцењивања у алтернативним концепцијама образовања: Валдорфске школе, Монтесори школе и Френеове школе.

\section{1. Оцењивање ученика у Валдорфским школама}

Валдорфска школа, утемељена на идеји немачког педагога Рудолфа Штајнера да је у образовању потребно узети у обзир целокупно биће детета, представља алтернативни концепт образовања са специфичном организацијом процеса оцењивања. Специфичност оцењивања ове концепције утемељена је на 
суштинским претпоставкама овог приступа међу којима се као значајне могу издвојити: (1) организовање наставе по епохама у којој ученици у периоду од три до четири недеље изучавају проблематику једне предметне целине (Milutinović, 2011); (2) стицање знања у изворној стварности или на примарним изворима знања у школи (Matijević, 2004); (3) овладавање практичним занатима који су неопходни за свакоднневни живот; (4) усмереност на социјализацију деце, јединствени развој духа и тела, естетски развој и др.

У Валдорфским школама је уобичајено да један наставник ради са ученицима у оквиру свих предмета током првих осам школских година чиме се између њега и ученика ствара присан однос пун поверења (Jagrović, 2007). Сараднички концепт оставрује се и свакодневним контактом наставника и родитеља. То значи да наставници, ученици и родитељи пуно времена проводе заједно чиме обавеза оцењивања и рангирања ученика постаје непотребна (Matijević, 2017) с обзиром на то да свакодневни рад са ученицима омогућује наставнику да упозна сваког од њих и да му помогне у савладавању школских задатака без оцена. На тај начин, наставник није посвећен програму и оценама, већ ученицима. Процес оцењивања у потпуности је усаглашен са приказаним концептом Валдорфских школа те наставник приликом прегледавања ученичких дневних радова може написати неки коментар, млађим ученицима нешто нацртати или се лепо потписати чиме им показује да цени њихов рад (Matijević, 2001). У Валдорфској школи се ученицима не додељују нити бројчане, нити неке друге, а посебно не негативне оцене, односно негује се пракса педагогије успеха за све. У основи овог приступа налази се претпоставка да сваки ученик током школске године нешто научи и оствари неки напредак, што значи да увек треба да буде позитивно поткрепљен могућношћу преласка у виши разред (Matijević, 2017). У Валдорфским школама се сви ученици посматрају као даровити и талентовани, а њихова евалуација се реализује у складу са тродимензионалном парадигмом, која наглашава значај физичких, емоционалних и когнитивних капацитета. Процени способности ученика прилази се на различите начине како би се утврдило да ли се оне развијају равномерно - ученици се посматрају у различитим ситуацијама и трага се за знацима здравља: пажња, ентузијазам, учешће у дискусијама и интересовања (Petrash, 2002).

У Валдорфској школи нема негативних оцена нити понављања разреда, али се на крају разреда за сваког ученика пише извештај који касније олакшава професионалну оријентацију ученика. Овај извештај садржи податке о ономе што је ученик радио током године - у чему је био успешан, које је пројекте радио, у чему је уживао (Matijević, 2017), какве је резултате остварио, да ли је остварио напредак, да ли поседује даровитост, које су му слабости и прогнозе за будући рад (Jagrović, 2007; Matijević, 2001). Уместо да учениково постигнуће оцени са „изванредно“, „задовољавајуће“ или „потребно побољшање“, наставник га описује, укључујући разноврсне ситуације, као и моменте у којима се ученик посебно истакао (Petrash, 2002), без икаквих словних или бројчаних оцена (Eugene, 2009). Извештај, како ученику, тако и родитељу, показује поштовање наставника према ученику и његову жељу да му помогне да постиг- 
не највише што може, те се избегавају негативни коментари који би могли да обесхрабре ученике (Matijević, 2001). Другим речима, вредновање је увек позитивно и подстицајно са нагласком на томе да се код ученика „не сме стварати комплекс мање вредности, нити култ успеха“" (Bezić, 1999: 443). Међутим, наставник има задатак да спомене и она подручја у којима би ученик требало више да напредује, што може представити у виду листе жеља уз наду да ће оне бити остварене у будућности (Petrash, 2002). Наставник, такође, описује и мере које ће сам предузети како би помогао у решавању „проблема“ ученика. Извештај садржи и пасус или два о учениковом напредовању које пишу наставници посебних предмета. Овај извештај је често допуњен и посебним извештајем који је намењен самом ученику. Он може бити написан као сажетак онога што је садржано у главном извештају, али обично је представљен у форми приче, песме, па чак и у виду цртежа или слике чиме наставник, на креативан начин, приказује природу детета (Eugene, 2009).

Описујући курикулум Валдорфских школа у Норвешкој, Матисен (Mathisen, 2014) наводи како су 2006. године уведене бројчане оцене како би ученици добили закључне оцене на трећој и на завршној години средње школе (Secondary School). Поред бројчаних оцена, ученици на крају школовања могу добити и писани извештај. У Валдорфским школама се, поред наведених, користе и други облици праћења напредовања ученика, од давања савета и коментара, преко систематских усмених и писмених повратних информација, до завршних извештаја, односно процена које ученик добија на крају сваке школске године. Приликом давања повратних информација наглашавају се позитивни аспекти учениковог рада, али то не значи да се не води рачуна о томе да процене буду истините и реалне. У првим годинама школовања, годишњи извештај добијају само родитељи, а ученици добијају континуиране повратне информације о свом раду у конкретним наставним ситуацијама, као и кроз разговор са наставницима. Касније, ученици такође добијају годишње извештаје. Осим тога, у каснијим годинама школовања, присутне су и процене од стране вршњака у којима ученици једни другима пружају повратне информације, а посебан нагласак је на развоју вештина самооцењивања. Такође, присутно је настојање да се наставникове процене што је више могуће ускладе са сликом коју ученик има о себи (Ibid.).

\section{2. Оцењивање ученика у Монтесори школама}

Монтесори школа темељи се на педагошкој методи Марије Монтесори, италијанског педагога и лекара (Cenić i Petrović, 2012), која се заснива на идеји слободног васпитања у одговарајућој средини и уз помоћ материјала за самосталне активности деце. У складу са тиме, централни мотив теорије и праксе ове алтернативне концепције јесте принцип педагошки припремљене околине (Milutinović, 2011). 
Оријентисана на: „поклањање довољно пажње детету, пружање слободе, посматрање и уочавање његових потреба, као и обезбеђивање довољно менталних подстицаја за његов развој“ (Minić, 2013: 155), организација рада у Монтесори школама омогућава ученицима да напредују својим темпом, самостално бирајући активности и радећи са јединственим дидактичким материјалима. Ове школе карактерише и „виртуално одсуство домаћих задатака, оцена и стандардизованих тестова“ (Dorhmann et al., 2007: 103). У процесу евалуације напредовања и развоја ученика се не примењују традиционални тестови и оцене (Edwards, 2002), већ концепти оцењивања који се не ослањају на стандардизоване начине процењивања академског успеха (Block, 2015). За оцењивање се користе аутентична средства и материјали на којима ученик практично показује своја знања и способности (Torrence, 2012) при чему се остварени резултати не процењују у односу на унапред постављене стандарде, већ према могућностима и индивидуалним карактеристикама ученика који, у зависности од своје зрелости, и сами учествују у процесу оцењивања и планирања својих активности (Jagrović, 2007; Matijević, 2001). Ученици су активно укључени у праћење сопственог напретка, што доводи до тога да са поносом деле одговорност за своје успехе и напредовање. У подели ове одговорности, појављују се и родитељи, као равноправни учесници (Kripalani, 1990). Сарадња наставника и родитеља представља основу праћења и подстицања ученика. За сваког ученика се сакупља и води посебна документација у оквиру које су обично истакнути циљеви које дете треба да достигне, а потом наставник заједно са родитељима процењује успешност детета у одређеним активностима. Оцене се бележе за потребе родитеља, ученика и школе (Matijević, 2001).

Полазећи од става да ученици постижу најбоље резултате у оним активностима које воле односно да радо учествују у оним активностима код којих су ослобођени страха од лоше процене Монтесори приступ тежи очувању унутрашње мотивације и поптуном занемаривању спосљашњих стимулса у настави. Из ових разлога Монтесори материјали конструисани тако да увек привлаче пажњу ученика и жељу да их користе, пружајући при томе повратну информацију о успешности извршеног задатака (Matijević, 2017). То значи да ученик показује своја знања практично их примењујући (Torrence, 2012), па, самим тим, обично нема потребу да наставника пита да ли је успешно извршио задатак и коју је оцену добио (Matijević, 2017).

Утемељена на представљеној концепцији, евалуација у Монтесори школама има следеће одлике: (1) циљ евалуације је да се превазиђе тестирање и одговорност према спољашњим притисцима, приликом чега ученик постаје ефикасни партнер у процесу евалуације сопствених резултата; (2) групе су састављене од ученика различитог узраста, а свако дете је истовремено „посматрач и сниматељ“ друге деце чиме се побољшава наставникова евалуација; (3) „контрола грешке“ омогућава ученику да вреднује свој рад и исправи своје грешке (рад са Монтесори материјалима); (4) да би наставник могао да врши евалуацију, неопходно је да континуирано прати процес учења који ученик остварује прелазећи са једног материјала на други; кроз учеников рад се могу из- 
мерити његове способности (истраживање, откривање, генерализација, проучавање, примена наученог); (5) учениково указивање на и исправљање грешака других ученика служи као основа за процену његових способности; (6) вођење евиденције о ученицима подразумева кратак преглед савладаних вештина (Kripalani, 1990).

\section{3. Оцењивање ученика у Френеовим школама}

Оснивач Френеове школе је Селестин Френе који је својом педагошком концепцијом настојао да превазиђе вербални и књишки карактер традиционалне школе. Френе одбацује наставу по предметима, наставне планове, програме и уџбенике, а залаже се за групни рад и за садржаје груписане по сродним подручјима. Основне одлике овог алтернативног приступа јесу настојање да се школа повеже са животом, учење ученика да посматрају природу у којој живе, да се слободно изражавају. Организација школског рада „треба да код ученика покрене одређена питања, више активности и стваралаштва“ (Cenić i Petrović, 2012: 155).

У школама које се темеље на Френеовој педагогији нагласак је на слободном избору стратегија, метода рада и модела праћења и оцењивања ученика.

Оцењивање подразумева самооцењивање ученика поређењем резултата које је остварио са личним плановима рада, као и оцењивање кооперативности у тимском, односно групном раду (Jorgović, 2007; Matijević, 2001). Улога наставника у процесу оцењивања огледа се у вођењу белешки о ученику, на основу којих му помаже да оптимално напредује (Matijević, 2001). Оцењивање у Френеовом систему представља специфичан вид сарадње између наставника, ученика и родитеља који потписују радне налоге ученика чиме стичу увид у оно што њихово дете ради и планира да ради (Jagrović, 2007). Радни налог, односно лични план радних активности ученик дефинише на крају сваке недеље уз наставникову помоћ (шта ће радити у области матерњег језика, математике, уметности, у школској штампарији). Овај план представља тзв. дидактички уговор који настаје кроз договор наставника, ученика и родитеља (Matijević, 2001) о индивидуалном програму за конкретног ученика, при чему родитељи и наставнци настоје да га мотивишу на оптимално залагање и остваривање својих могућности (Matijević, 2005). Дидактички уговор, односно договор, се може применити и у пракси редовног образовања обухватајући понашање наставника и ученика, односно обавезе наставника, као и захтеве и очекивања које ученик треба да оствари. На почетку наставног процеса, наставник би ученицима објаснио очекиване исходе и правила понашања којих се притом треба придржавати. Веома је важно да наставник стекне слику о ученицима како би планирао индивидуализоване наставне активности у зависности од њихових могућности (допунска настава, додатна настава, пројекти, менторство итд.). У свему томе, наставник неће сам решавати проблеме у вези са развојем и потребама ученика, већ кроз сарадњу са родитељима (Matijević, 2011).

Савременост, ефикасност и ефективност наведеног концепта резултирала је многоборојним примерима у савременој пракси. Један од примера савре- 
мене примене Френеовог модела кооперативног оцењивања представља курс Wirtschaftsinformatik (Економска информатика). Осмишљен у складу са принципима Френеове педагогије, курс темељи оцењивање на сарадњи наставника и студената у: прегледавању појединачних радова, презентација, документације и доношењу одлука о оцени. Такође, студентима се пружа прилика да исправе недостатке идентификоване приликом прегледавања рада и, у том случају, коначну оцену одређује наставник (Oppl, 2016).

Други, вредан модел оцењивања на принципима Френеове школе представља пилот експерименту Кузнетсове и Регнера (Kuznetsova \& Régnier, 2014) у коме је једносемстрални курс страног језика реализован без уџбеника, текстова, радних листова или других готових материјала. У експерименту нису коришћене традиционалне оцене, већ је осмишљен посебан систем бодовања. Студент има могућност да сакупи бодове извршавањем било ког задатка. Сваки задатак носи одређени број бодова, који је студентима унапред познат, а на коначну оцену утиче исправност рада и усклађеност са предвиђеним роковима. Додатни поени могу се освојити извршавањем додатних задатака. Дакле, нагласак је на остваривању могућности да студент сам креира свој индивидуални план учења. Поред тога, оцењивање често укључује и дискусију са студентима како би се разјаснили проблеми са којима су се сусретали у процесу рада, и како би се пронашли начини за њихово превазилажење. Резултате неких задатака ученици су процењивали сами у току тзв. сесија самоевалуације (Kuznetsova \& Régnier, 2014). Резултати овог пилот експеримента потврдили су ефикасност Фреинетових наставних метода у смислу подстицања мотивације студената. Индивидуализација наставног рада и оцењивања омогућила је студентима да индивидуализује своје циљеве и начине њиховог остваривања што за крајњи резултат има висок ниво њихове мотивације за успешно учешће и оставривање тако дефинсианих циљева.

\section{Закључак}

Насупрот оцењивању у систему редовног образовања, у коме обично важи да је оцена мерило знања, „мерење“ знања ученика у алтернативним школама није стављено у први план. Својом тежњом ка развоју личности ученика, алтернативне школе су фокусиране на индивидуалне карактеристике сваког од њих како би се подстицајном средином и начинима рада развили њихови потенцијали и могућности. И само оцењивање је у функцији мотивисања развоја и напредовања ученика. Анализом проблема оцењивања из алтернативног приступа образовању, можемо закључити да оцењивање ученика у алтернативним школама карактерише:

(1) Холистички приступ. Оцењивање се не своди на запамћивање чињеница. Оцена је резултат праћења и упознавања ученика као целовите личности. Уважава се и његово мишљење и делање. Нагласак је на практичној примени знања. 
(2) Могућност индивидуализаиије. Оцењивање је усклађено са индивидуалним карактеристикама ученика. У обзир се узимају његове личне могућности и способности. Нема унапред постављених стандарда.

(3) Мотивачија ученика насупрот категоризацији ученика. Ученици се не деле на „добре“ и „лоше“ ђаке. Оцењивање је у функцији њиховог охрабривања за нове успехе. Наглашене су позитивне стране учениковог рада, а његови недостаци се не критикују, већ се траже решења за њихово превазилажење. (4) Заједничка одговорност и сарадњ а у пориесу оцењивања. Оцењивање се заснива на сарадњи наставника, ученика и родитеља. Родитељи су активно укључени у праћење напредовања ученика и са наставником и дететом деле одговорност за превазилажење евентуалних недостатака. У оцењивање се укључују и други ученици.

(5) Повратна информачија као основа самоевалуащије. Ученик је правовремено информисан о свом напредовању што му омогућава сагледавање својих предности и недостатака. Циљ је оспособити ученика за самоевалуацију.

(6) Одсуство репресивне улоге оцењивања. Ученик нема страх од одговарања, писмених и контролних провера знања. Учење представља задовољство.

Наведене карактеристике недвосмислено указују на вредности система евалуације и оцењивања приказаних алатернативних школа и пружају могућност за креирање иновативних техника и механизама процене којима се може обезбедити квалитет и ефикасност процеса оцењивања и у систему редовног образовања и наставе. Такође, наведени модели могу послужити и као основа на креирање индивидуализованих поступака оцењивања којима наставници практичари могу у значајној мери унапредити своју праксу и оцењивање у већој мери ставити у функцију развоја ученика.

\section{Литература}

Bezić, Ž. (1999). Waldorfska pedagogija. Crkva u svijetu, 34(4), 437-449.

Biasiol Babić, R. (2009). Vrednovanje i ocjenjivanje s posebnim osvrtom na učenike s teškoćama u razvoju integrirane u redovni sustav odgoja i obrazovanja. Metodički obzori, 4(1-2), 207-219.

Block, C. R. (2015). Examining a Public Montessori School's Response to the Pressures of High-Stakes Accountability. Journal of Montessori Research, 1(1), 42-54. Retrieved 03.05.2018. from: https://files.eric.ed.gov/fulltext/EJ1161298.pdf

Bognar, L., Matijević, M. (2002). Didaktika. Zagreb: Školska knjiga.

Cable, K. E., Plucker, J. A. \& Spradlin, T. A. (2009). Alternative Schools: What's in a Name?. Education Policy Brief, 7(4), 1-12.

Cenić, S. i Petrović, J. (2012). Vaspitanje kroz istorijske epohe. Vranje: Učiteljski fakultet.

Dorhmann, K. R., Nishida, T. K., Gartner, A., Lipsky, D. K. \& Grimm, K. J. (2007). High School Outcomes for Students in a Public Montessori Program. Journal of Research in Childhood Education, 22(2), 103-114. 
Edwards, C. P. (2002). Three approaches from Europe: Waldorf, Montessori, and Reggio Emilia. Early Childhood Research \& Practice, 4(1). Retrieved 05.05.2018. from: https://files.eric.ed.gov/fulltext/ED464766.pdf

Eugene, S. (2009). Discover Waldorf Education: Assessing Without Testing. Retrieved 15.05.2018. from: https:/www.bayouvillageschool.org/uploads/5/1/2/1/5121407/ assessing_without_testing.pdf

Jagrović, N. (2007). Sličnosti i razlike pedagoških modela Marije Montessori, Rudolfa Steinera i Célestina Freineta. Školski vjesnik, 56(1-2), 65-77.

Kripalani, L. A. (1990). Towards a Montessori Evaluation Approach. In D. Kahn (Ed.), Implementing Montessori Education in the Public Sector (pp. 613-618). Cleveland, $\mathrm{OH}$ : North American Montessori Teacher's Association.

Kuznetsova, E. \& Régnier, J. C. (2014). Individualization of Educational Process according to C. Freinet: a Pilot Experiment in a Group of Language Learners. Procedia - Social and Bihevioral Sciences, 154, 87-91.

Martin, R. A. (2004). Philosophically Based Alternatives in Education. Encounter: Education for Meaning and Social Justice, 17(1), 17-27.

Mathisen, A. (2014). A Curriculum for Norwegian Waldorf Schools. Overview - Ideas and Practices in Waldorf Education. Retrieved 05.05.2018. from: http://www. arvema.com/tekster/Ideas_and_Practices_Introduction_Norwegian_Waldorf_ curriculum_2014.pdf

Matijević, M. (2001). Alternativne škole. Zagreb: Tipex.

Matijević, M. (2005). Evaluacija u odgoju i obrazovanju. Pedagogijska istraživanja, 2(2), 279-298.

Matijević, M. (2011). Pedagoški vid vrednovanja i ocenjivanja učenika. U B. Drandić (Ur.), Pravno-pedagoški priručnik za osnovne i srednje škole (str. 241-251). Zagreb: Znanen.

Matijević, M. (2017). Izazovi vrednovanja škole i u školi. U G. Latinović (Ur.), Banjalučki novembarski susreti 2016: Zbornik radova sa naučnog skupa (str. 93-118). Banja Luka: Filozofski fakultet.

Milutinović, J. (2011). Alternative u teoriji i praksi savremenog obrazovanja - put ka ka kvalitetnom obrazovanju. Novi Sad: Savez pedagoških društava Vojvodine.

Milutinović, J. i Zuković, S. (2011). Aktuelnost reformne pedagogije: model slobodnih i demokratskih škola. Pedagoška stvarnost, 57(5-6), 426-437.

Milutinović, J. \& Zuković, S. (2013). Educational Tendencies: Private and Alternative Schools. Croatian Journal of Education, 15(2), 241-266.

Minić, V. (2013). Pedagoške ideje Marije Montesori i njihova primena u praksi. Naše stvaranje. Zbornik radova sa Osnog simpozijuma sa međunarodnim učešćem "Vaspitač u 21. Veku", Aleksinac: Visoka škola za vaspitače. 145-156

Nagata. Y. (2006). Alternative Education: Global Perspectives Relevant to the AsiaPacific Region. Dordrecht, Netherlans: Springer.Ž

Oppl, S. (2016). Adopting Concepts of Freinet Pedagogy in Higher Education. Retrieved 16.05.2018. from: https://www.researchgate.net/publication/307577796_Adopting Concepts_of_Freinet_Pedagogy_in_Higher_Education_A_Report_on_the_Design and_Evolution_of_a_Didactical_Experiment 
Petrash, J. (2002). Understanding Waldrof Education: Teaching from the Inside Out. Beltsville, MD: Gryphon House.

Reimer, M. S. \& Cash, T. (2003). Alternative Schools: Best Practices for Development and Evaluation. Clemson, SC: National Dropout Prevention Center.

Siegrist, J., Drawdy, L., Leech, D., Gibson, N., Stelzer, J. \& Pate, J. (2010). Alternative Education: New Responses to an Old Problem. Journal of Philosophy and History of Education, 60, 133-140.

Torrence, M. (2012). Montessori Education: An Idea Whose Time Has Come?, Montessori Life, 24(2), 18-23.

\title{
STUDENT ASSESSMENT IN ALTERNATIVE SCHOOLS
}

Tamara Vukić

University of Niš , Faculty of Philosophy, Pedagogy Department, PhD student,

\author{
Marija Jovanović \\ University of Niš , Faculty of Philosophy, Pedagogy Department
}

\begin{abstract}
The main prerequisites for ensuring the quality of education and the teaching process are the qualitative features of the assessment process and its efficiency. In order to show the benefits, role and importance of assessment characteristics that have been significantly neglected or completely absent in the formal education system, this paper presents an overview of alternative schools in which the evaluation and assessment process is based on such qualitative approaches. The paper presents the general characteristics of the education activities of the Waldorf School, Montessori School and Freinet's School, with particular reference to the assessment and evaluation process. Based on the assessment characteristics in the abovementioned alternative schools, it can be concluded that this process is characterized by: a holistic approach; high level of individualization; motivation in place of categorization; collaboration and shared responsibility of teachers, students and parents; timely feedback as the foundation for self-evaluation and the absence of repressive effect of evaluation. The identified characteristics provide an opportunity to create innovative assessment techniques and mechanisms that can ensure the quality and efficiency of the assessment process in the formal education system and serve as the foundation for creating individualized assessment procedures which the teachers-practitioners can use to significantly improve their teaching skills and use assessment more as a tool for student development.
\end{abstract}

Key words: assessment, alternative schools, Waldorf School, Montessori School and Freinet's School

\section{Citiranje članka:}

Jovanović, M. i Vukić, T.(2020). Ocenjivanje učenika u alternativnim školama.

Godišnjak za pedagogiju, 5(2), 51-60. 